\title{
International
}

\section{The 2010 APSA Workshop on Global Perspectives on Politics and Gender: Dar es Salaam, Tanzania, July 18 -August 6, 2010}

\section{Helena Saele, Program Associate, International and External Relations}

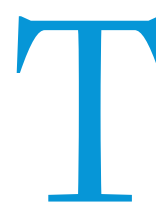

he APSA Workshop on Global Perspectives on Politics and Gender was convened in Dar es Salaam, Tanzania, from July 18 to August 6. It was the third annual residential workshop of a multiyear initiative that APSA is organizing in sub-Saharan Africa from 2008 though 2014. The first workshop took place in Dakar, Senegal (2008), at the facilities of the West African Research Center; the second workshop was convened in Accra, Ghana (2009), at the Institute for African Studies and the University of Ghana, Legon.

This workshop series is generously supported by a grant from the Andrew W. Mellon Foundation and is a key part of APSA efforts to support the development of applied research networks linking U.S.-based scholars with colleagues overseas and supporting political science communities outside the United States.

The Dar es Salaam workshop was hosted by the Gender Centre at the University of Dar es Salaam, Tanzania. It brought together 26 political scientists: 18 Africa-based participants from 11 different countries and four U.S.-based participants who were competitively selected last spring, in addition to the four workshop leaders (two U.S.-based, two Africa-based). This diverse group included 18 women and eight men, as well as scholars ranging in age from their twenties to their early fifties. The full roster included:

- Olajide Akanji, Nigeria

- Agnes Apusigah, Ghana

- Bonnie Ayodele, Nigeria

- Naima Benlarabi, Morocco

- Lotsmart N. Fonjong, Cameroon

- Peace Medie, Ghana

- Chiseche Salome Mibenge, Zambia

- Sethunya Mosime, Botswana

- Olajumoke Yacob-Haliso, Nigeria

- Uchenna Idoko, Nigeria

- Oyeleye Oyelade Dairo, Nigeria

- Daniel Kere, Burkina Faso

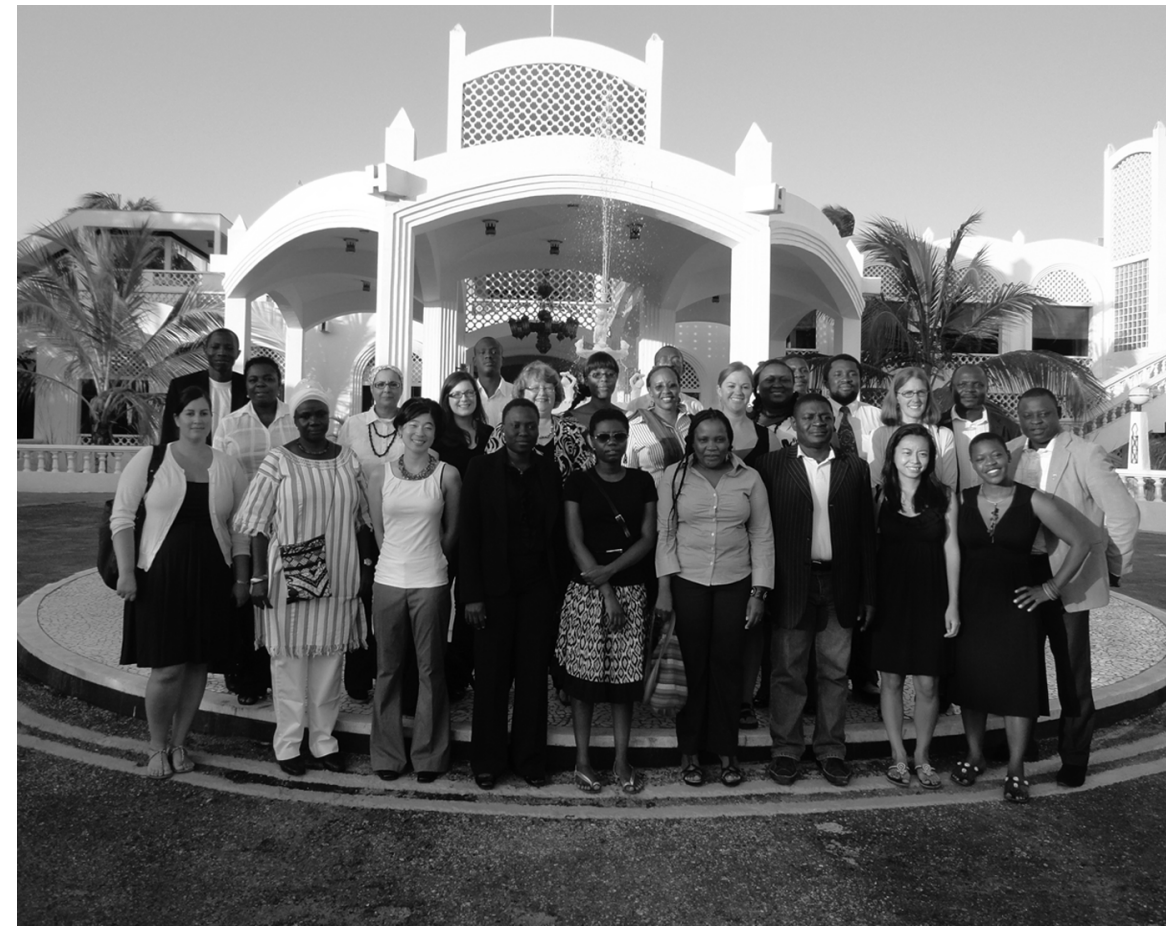

Participants in the 2010 Workshop on Global Perspectives on Politics and Gender, held in Dar es Salaam, Tanzania

- Anne Karanja, Kenya

- Rasel Madaha, Tanzania

- $\quad$ Lydia Apori Nkansah, Ghana

- Freedom Onuoha, Nigeria

- Herman Touo, Cameroon

- Alex Ng'Oma, Zambia

Four U.S.-based graduate students were also selected to participate:

- Kara Ellerby, University of Arizona

- Alice Kang, University of Wisconsin- Madison

- Ayuko Nimura, Northwestern University

- Taylor Price, University of Wisconsin-Madison ed:

The 2010 workshop leaders includ-

- Gretchen Bauer, department of

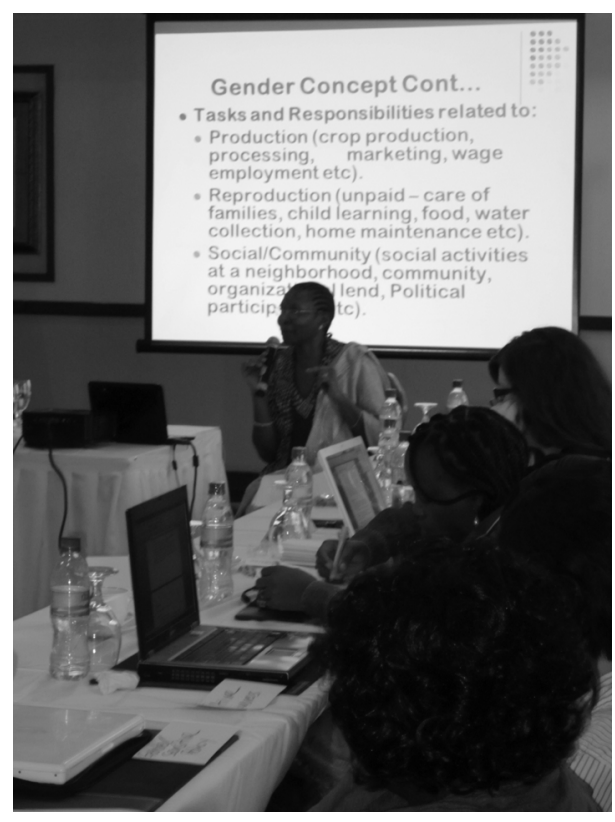

Participants listen to Dr. Fenella Mukangara from the Gender Centre, University of Dar es Salaam 
political science and international relations, University of Delaware

- Shireen Abdool Aziz Hassim, department of political studies, University of the Witwatersrand, South Africa

- Fenella Mukangara, Gender Centre, University of Dar es Salaam, Tanzania

- $\quad$ Aili Mari Tripp, department of political science, University of Wisconsin-Madison

A special word of thanks goes to the USDM Gender Centre staff and the four workshop leaders for their respective roles in this very successful event.

For more information on the 2010 workshop or the overall project, including the calendar, picture galleries, syllabi, reading lists, and the official Workshop Proceedings, please visit the project Web site at www.apsanet.org/africaworkshops or contact us directly at africaworkshops@apsanet.org.

APSA is currently seeking applications from those interested in serving as workshop leaders for the 2011 APSA Workshop. The application deadline is October 15, 2010. For more information, please visit www.apsanet. org/africaworkshops.

\section{APSA INTERNATIONAL MEMBERSHIP}

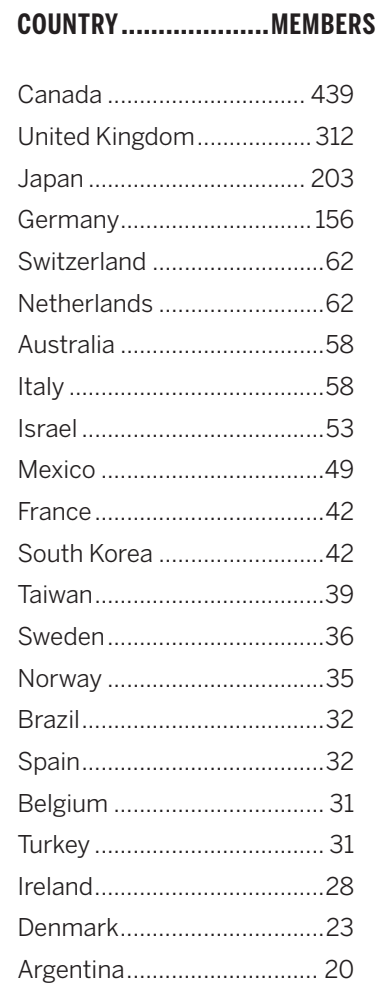

Peru........................................... 4

Saudi Arabia .............................4

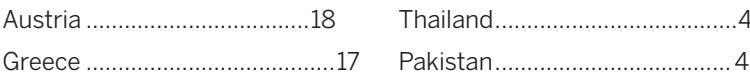

Greece .................................17

Hong Kong, China .................... 16

New Zealand.............................15

China.......................................15

Russia .......................................14

India .......................................13

Poland ......................................12

Finland ...................................12

Hungary .....................................12

Czech Republic .......................... 11

South Africa ............................. 9

Nigeria ....................................... 9

Portugal ...................................... 9

Cameroon .................................... 9

Ukraine ........................................ 7

Indonesia.................................... 6

Romania ....................................6

Burkina Faso ............................. 6

Scotland ................................... 6

United Arab Emirates .................5

Venezuela .................................. 4

Bulgaria .................................... 4

Lebanon....................................... 4

Senegal ...................................... 4

Croatia ........................................ 4

Colombia, Benin, Azerbai-

jan .......................... 3

Philippines, Iran, BosniaHerzegovina, Egypt, Kenya, Ghana, Cyprus, Congo, Nepal, Qatar, Armenia, Slovenia,

Macao ............................. 2

Jamaica, Dominican Republic, Trinidad \& Tobago, Costa Rica, Honduras, Malaysia, Bolivia, Kuwait, Bahrain, Jordan, Iceland, Iraq, Algeria, Sri Lanka, Luxembourg, Albania, Bhutan, East Timor, Ivory Coast, Latvia, Madagascar, Mali, Mozambique, Macedonia (Republic of), Montenegro, Slovak Republic (Slovakia) ...................................... 1

Report Totals 2,567

\section{UPCOMING INTERNATIONAL EVENTS}

\section{0}

November 4-6:

November 10-11:

December 13-14:

December 15-19:

2011

January 27-28:

January 27-29:
Association for the Study of the Middle East and Africa (ASMEA) 3rd Annual Conference on "The Middle East and Africa in the 21st Century: Local Trends, Regional Challenges, Global Impacts," Washington, DC, https:/www.asmeascholars.org/ index.php?option=com_content $\&$ view=article\&id=1306\&Itemid=91.

English and German Nationalist and Anti-Semitic Discourse, University of London, UK, http://www.sllf.qmul.ac.uk/research/nationalismproject/

Challenging Orthodoxies-The Critical Governance Studies Conference 2010, University of Warwick, Coventry, UK, http://www2.warwick.ac.uk/fac/soc/wbs/projects/ orthodoxies/

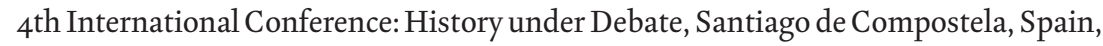
http://www.h-debate.com/congresos/4/menu_def_ing.htm

Sexual Nationalisms: Gender, Sexuality and the Politics of Belonging in the New Europe, University of Amsterdam, The Netherlands, http://www.aissr.uva.nl/aissr_ news/agenda.cfm/D4D76575-D21B-46D7-A2CABB $3 \mathrm{~F}_{731} \mathrm{E}_{52} \mathrm{~A} 2$

4th Annual Conference on the Political Economy of International Organizations, Zurich, Switzerland, http://www.peio.me/. 